\title{
Cultural Heritage Education in UNESCO Cultural Conventions
}

\author{
Alicja Jagielska-Burduk*(D), Mateusz Pszczyński and Piotr Stec (D) \\ Institute of Law, University of Opole, 45-060 Opole, Poland; mpszczynski@uni.opole.pl (M.P.); \\ pstec@uni.opole.pl (P.S.) \\ * Correspondence: ajagielska@uni.opole.pl
}

check for

updates

Citation: Jagielska-Burduk, A.; Pszczyński, M.; Stec, P. Cultural Heritage Education in UNESCO Cultural Conventions. Sustainability 2021, 13, 3548. https://doi.org/ $10.3390 /$ su13063548

Academic Editors: Cosme Jesús Gómez-Carrasco, José Monteagudo-Fernández, Pedro Miralles-Martínez and Olaia Fontal-Merillas

Received: 26 January 2021

Accepted: 19 March 2021

Published: 23 March 2021

Publisher's Note: MDPI stays neutral with regard to jurisdictional claims in published maps and institutional affiliations.

Copyright: (C) 2021 by the authors. Licensee MDPI, Basel, Switzerland. This article is an open access article distributed under the terms and conditions of the Creative Commons Attribution (CC BY) license (https:/ / creativecommons.org/licenses/by/ $4.0 /)$.

\begin{abstract}
The aim of the article is to analyse UNESCO conventions dealing with culture and assess the visibility and importance of cultural heritage education in these conventions and their implementation. First, it briefly presents the role of UNESCO in the area of culture and education, together with the UN Agenda 2030 and the challenges faced currently. Next, it discusses the existing UNESCO cultural conventions and their educational dimension with reference to the conventions' provisions and aims. Each convention refers to education in the activities undertaken by States Parties, providing various tools and measures tailored to the scope of the convention. The article concludes that despite a lack of synergy and creation of education-related programs in convention-related siloes, UNESCO has managed to create a uniform and evolving system of educational measures aimed at various stakeholders and focus on various levels of awareness. Cultural heritage education is an imminent part of activities undertaken within States' obligations and should involve various stakeholders, building networks and existing in synergy with other actions or campaigns based on different conventions.
\end{abstract}

Keywords: cultural heritage; UNESCO; cultural conventions; education; awareness raising

\section{Introduction}

UNESCO (the United Nations Educational, Scientific and Cultural Organization) is an international organization with 193 Member States. It was established in 1945 as a specialized agency of the United Nations. Article 1 (1) of the UNESCO Constitution states: "The purpose of the Organization is to contribute to peace and security by promoting collaboration among the nations through education, science and culture in order to further universal respect for justice, for the rule of law and for the human rights and fundamental freedoms which are affirmed for the peoples of the world, without distinction of race, sex, language or religion, by the Charter of the United Nations" [1]. Audreu Azoulay (Director-General of UNESCO) recently said: "Let us reaffirm the primacy of education, science, culture and knowledge to help us surmount crisis," in reference to the COVID-19 pandemic [2]. In these challenging times, many initiatives have shifted online, including various initiatives in the field of cultural heritage. Therefore, educational activity has taken on a much greater priority in light of this digital migration. This type of activity aims to raise awareness of cultural heritage protection, while also enabling Internet users to access culture from distant places, join in cultural events, or visit exhibitions.

UNESCO's pivotal role in the field of culture, science, and education leads to sustainable reinforcement of the existing legal framework in the area of cultural heritage protection. The existing legal framework in terms of cultural heritage protection is made more complementary by introducing new international legal instruments and promoting their ratification by Member States. For over 70 years, UNESCO has provided new documents, legal tools, and organizes actions together with other international, regional, and local actors in this field.

The protection of cultural heritage is perceived as a global obligation. Cultural heritage is a non-renewable resource, so its destruction or loss impoverishes world culture as a 
whole. Therefore, preventive actions are essential. Educational campaigns form an integral part of cultural heritage protection by raising awareness of its importance. Thus far, UNESCO has been crucial in developing the existing legal framework in the area of culture. Under the umbrella of UNESCO, the international community has adopted six conventions in this field:

1. Convention for the Protection of Cultural Property in the Event of Armed Conflict with Regulations for the Execution of the Convention, signed in the Hague 1954 (hereinafter: 1954 UNESCO Convention) [3-5] with 133 ratifications (Less countries ratified 1st 107 and 2nd Protocol 83.)

2. Convention on the Means of Prohibiting and Preventing the Illicit Import, Export and Transfer of Ownership of Cultural Property 1970 (hereinafter: 1970 UNESCO Convention) [6] with 140 ratifications

3. Convention concerning the Protection of the World Cultural and Natural Heritage 1972 (hereinafter: 1972 UNESCO Convention) [7] with 194 ratifications

4. Convention on the Protection of the Underwater Cultural Heritage 2001 (hereinafter: 2001 UNESCO Convention) [8] with 67 ratifications

5. Convention for the Safeguarding of the Intangible Cultural Heritage 2003 (hereinafter: 2003 UNESCO Convention) [9] with 180 ratifications

6. Convention on the Protection and Promotion of the Diversity of Cultural Expressions 2005 (hereinafter: 2005 UNESCO Convention) [10] with 149 ratifications

Cultural heritage is a broad concepts with many dimensions (movable, immovable, tangible and intangible. The definitions of cultural heritage and education are highly contested in the social sciences. This research, however, focuses on cultural heritage and education as defined in the relevant legal acts or documents cited herein. These definitions have been deliberately drafted broadly in order to accommodate stakeholders' needs and to enable progressive interpretation [11-15].

For instance, in UNESCO documents the terms cultural property, cultural heritage manifestations and cultural heritage are often defined for the purpose of the particular document or convention. It is undisputed that the protection of cultural heritage contributes to the sustainable development and UN Agenda 2030. The notions of culture and education are interlinked and appear in several Agenda 2030 goals. During the second Coordination Meeting of Category 2 Centres and UNESCO Chairs related to Culture, [16] Mechtild Rössler emphasized that the role of cultural heritage in sustainable development is multidimensional and arises from various goals. In this field, she strengthened the role of education and contribution by members of academia. Agenda 2030 foresees cultureand cultural heritage-engaged implementation of the SDGs. Among the most obvious and intuitively linked to cultural heritage, the following SDGs are worthy of mention:

4.7 By 2030, ensure that all learners acquire the knowledge and skills needed to promote sustainable development, including, among others, through education for sustainable development and sustainable lifestyles, human rights, gender equality, promotion of a culture of peace and non-violence, global citizenship and appreciation of cultural diversity and of culture's contribution to sustainable development. 8.9 By 2030, devise and implement policies to promote sustainable tourism that creates jobs and promotes local culture and products.

11.4 Strengthen efforts to protect and safeguard the world's cultural and natural heritage.

16.4 By 2030, significantly reduce illicit financial and arms flows, strengthen the recovery and return of stolen assets and combat all forms of organized crime.

16.a Strengthen relevant national institutions, including through international cooperation, for building capacity at all levels, in particular in developing countries, to prevent violence and combat terrorism and crime. 
17.17 Encourage and promote effective public, public-private and civil society partnerships, building on the experience and resourcing strategies of partnerships.

Nowadays, cultural heritage protection is an international effort and involves many actors. This includes not only states and public parties, but also communities, NGOs, and individuals. Only strong international cooperation can guarantee cultural heritage protection and ensure its proper role in global development. When ratifying conventions, states are obliged to implement their provisions and fulfil their respective obligations. The protection of cultural heritage at the national level requires an efficient administrative apparatus responsible for the implementation of cultural heritage protection policy and specific law governing this area, together with instruments enabling its efficient and effective implementation. However, even the most perfect legislation and a good level of administration will not ensure full success. Building links between citizens and cultural heritage, and stimulating its development by including them in cultural heritage management is essential. The latter should be integrated with cultural heritage education for greater success (hereinafter: $\mathrm{CHE}$ ).

Therefore, it is necessary to address this subject and to determine whether and to what extent CHE and educational measures are discussed in the UNESCO conventions. The authors aim to analyse to what extent the conventions' provisions constituting the basis for initiatives undertaken in each field are consistent with and complementary to each other. The authors intend to supplement previous research on the role of CHE in the European Union and the Council of Europe Cultural Heritage and Education Policy [17,18].

\section{Materials and Methods}

The proposed research is a classical academic research work in legal science. Thus, it is not based on quantitative analysis of research samples. Unlike qualitative social sciences, mainstream academic legal research is focused on decoding the meaning of primary legal sources in order to apply legal norms in practice. We have adopted classical methods of legal research. For this purpose, a black letter analysis of legal texts was used, supplemented by official explanations such as Operational Guidelines, views of doctrine and comments. The article is based on primary and secondary sources concerning the referenced legal acts available in university libraries, international databases (such as SCOPUS, ERIH Plus, Web of Science) and the documents available on the official UNESCO website. For instance, UNESCO maintains data in its Database of National Cultural Heritage Laws on State Party Reports, containing information about ongoing projects provided by Member States. The data in this work is either publicly available or was obtained from commercial databases for legal scholars. The conventions' educational dimension will be presented in chronological order based on their date of adoption. We analysed UNESCO cultural conventions in order to show whether UNESCO responds to current challenges in cultural heritage education adequately, and how education is anchored in the conventions' texts. The authors aim to present the conventions' declared objectives and how UNESCO envisions practical implementation of said objectives. This is an attempt to create a roadmap of what is commonly called law in books, which will then be reflected by the actions of UNESCO and other stakeholders, including non-state communities. This is the first part of a larger research project devoted to law and the practice of global cultural heritage education within UNESCO.

\section{Analysis}

\subsection{The 1954 UNESCO Conventions}

The awareness that cultural resources are important to individual countries has developed strongly alongside the impact of culture on flourishing societies. The first references condemning the plundering of works of art already appeared in the works of Cicero and Polybius many centuries ago [19] (pp. 75-78). Awareness and knowledge concerning the importance of cultural heritage have evolved over time. The tragedies of the First and Second World Wars, as well as the development of technology and access to information, 
have significantly contributed to changes in perspective. Awareness of the subject matter and cooperation within the framework of the United Nations and UNESCO prompted the adoption of the 1954 UNESCO Convention [3], which led to "the gradual maturing of public attitudes" enabling the prosecution of attacks on cultural heritage as war crimes [20] (p. 18).

In the 1954 UNESCO Convention's Preamble, it was recognized that damage to cultural property represents damage to the cultural heritage of all mankind, no matter which nation it belongs to. Its loss, or risk of destruction, may threaten the identity of a particular nation or ethnic group. At the same time, it impoverishes the heritage of the whole of humanity, even if this is not immediately apparent at the moment of destruction. In consequence, the definition of cultural property given in Article 1 refers to such objects irrespective of origin or ownership.

The scope of the 1954 UNESCO Convention's protection is holistic in nature, as it covers actions to be taken by a State during peacetime in order to secure cultural resources within its own territory (Article 3) [21] (p. 33). At the same time, it combines this obligation with actions to be taken at the time of armed conflict (Article 4), as well as those taken during occupation (Article 5). In such periods, cultural heritage should be removed or protected from the theatre of war and used during peacetime in such a way that there would be no conceivable threat of destruction in the event of armed conflict.

To fulfil all of the responsibilities mentioned above in light of Article 7 of the 1954 UNESCO Convention, all parties to the Convention should introduce internal provisions in the form of regulations or instructions to their armed forces, to ensure a spirit of respect for the culture and cultural property of all peoples. According to Techera, there is no obligation to pass on these values and knowledge to civilians [22]. On the other hand, it is impossible to agree with this position unreservedly, as Article 7 of the 1954 UNESCO Convention should be read along with Article 25, concerning the dissemination of the international agreements' content. Among others, Schreiber is in favour of interpreting Article 7 alongside Article 25 [23].

According to Article 25 of the 1954 UNESCO Convention, entitled "Dissemination of the Convention", States Parties are obliged to disseminate the text of the Convention and its implementing provisions as widely as possible. Particular attention should be paid to the need to incorporate the principles of the 1954 UNESCO Convention into the curricula of the armed forces. Moreover, awareness-raising and dissemination activities should also be carried out among civilians. It is obvious that without the common knowledge of applicable law, there can be no reference to its respect or compliance.

It therefore appears that the States Parties should take extensive action in this area, both in times of peace and armed conflict.

Articles 7 and 25 of the 1954 UNESCO Convention are supplemented by Article 30 of the Second Protocol to the 1954 Convention [5]. The addressees of this standard are the States Parties to the Second Protocol, who are obliged to take all appropriate measures to strengthen respect for and recognition of the value of cultural goods in society. Roger O'Keefe points that this precondition is "the least amenable to government action" [24]. The provisions on dissemination in the Second Protocol are aligned with those on international assistance and UNESCO's assistance and international cooperation. Actions to promote the Second Protocol and the 1954 UNESCO Convention simultaneously are to be taken both in the time of peace and during armed conflict. At the same time, the military or civil authorities responsible for the application of the Second Protocol should be familiar with its content. To do so, military regulations should recall the text of the Second Protocol, as should civilian educational programmes promoting and raising awareness of cultural property protection. The States Parties should inform each other of the measures taken, both educational and regulatory, to ensure the application of the Second Protocol.

Educational activity in the protection of cultural property in armed conflict for military forces is prepared by State Parties. Its form varies from educational courses to support from archeologists in situ, pocket guides, and brochures, to playing cards with decks 
representing cultural property and legal reminders (such as 'buying looted artefacts is illegal. They will be confiscated and you risk a criminal record'). Training materials are also developed by UNESCO in this area [25] (pp. 19-20). An interesting example is that of cards with information on how to recognise cultural heritage and those showing cultural property photos, which form the part of the preparation for military action outside the country [26]. It is worth mentioning that NATO is also making educational efforts by issuing relevant publications $[27,28]$ or providing training prior to missions in areas of armed conflict [29].

It should be noted that armed conflicts can have different dimensions in the current political sphere. In particular, those of a terrorist nature and hybrid wars, including cyber-attacks, require a new approach to the protection of cultural assets. Educational and promotional actions should be taken into consideration and tailored to respond to both those challenges. New channels of communication, economic instruments used by the coming 4th Industrial Revolution, and the opportunities offered by artificial intelligence, military and civilian ones, all work to promote and protect cultural assets in this context. Well-coordinated efforts may result in the better protection of cultural property. International cooperation in the educational sphere in the event of war or armed conflict can have a significant positive impact on the preservation and the use of cultural property both during the conflict and in times of peace.

\subsection{The 1970 UNESCO Conventions}

The issue of the illegal export of cultural assets has been a feature of international discussions over many years and ultimately developed into the 1970 UNESCO Convention [6]. This convention represents a milestone in the fight against the illegal trade in cultural property. As the first international instrument in this field, the convention both kickstarted and further intensified existing debates on the legal treatment of illicitly exported and trafficked cultural property. One of the convention's key results was the creation of the subsequent UNIDROIT 1995 Convention [30] covering some aspects that were omitted in the 1970 UNESCO Convention.

The 1970 UNESCO Convention is based on three pillars-restitution provisions, preventive measures and international cooperation-which are interconnected and complementary. International cooperation is developed within the third pillar. In this large cooperative, the following actors are involved, among others: the European Union [31,32], the United Nations Office on Drugs and Crime (UNODC), the International Council of Museums (ICOM), the International Institute for the Unification of Private Law (UNIDROIT), Interpol, and the World Customs Organisation. Upon ratification of the 1970 UNESCO Convention, the States Parties undertake to set up within their territories one or more national services for the protection of cultural heritage, including "tak[ing] educational measures to stimulate and develop respect for the cultural heritage of all States, and spreading knowledge of the provisions of this Convention" (Article 5(f)). The educational activities mentioned in this article, "including public education campaigns and sensitization on cultural heritage importance, laws and protection measures" [33] (p. 5) are on the countries' check-list for national legislation in terms of the 1970 Convention. Educational campaigns aimed at raising awareness are perceived as preventive measures [34] (p. 29). The authorities are responsible for the protection of their own cultural property, but educational measures seek to cover the world's heritage in general. It should be noted that some countries have been developing appropriate services since time immemorial, but it was only the restoration of sovereignty for several states in the 20th century that resulted in the establishment of appropriate conservation and police structures; cooperation and technical assistance by UNESCO are therefore extremely important (Article 17).

Member States' educational and informational activities contribute to the improvement of legal awareness. Article 10a includes education as one of the suggested means to influence antiquities dealers to keep data on transactions and inform potential buyers on export permit requirements. Education as a broad concept is embedded in Article $10 \mathrm{~b}$ 
as States Parties undertake "to endeavour by educational means to create and develop in the public mind a realization of the value of cultural property and the threat to the cultural heritage created by theft, clandestine excavations and illicit exports". Since theft and illegal excavations are crimes that often coexist or precede the illegal export of cultural goods, such interconnections should also appear in educational campaigns. Preventive measures not only broaden citizens' knowledge and sensitize them to their own culture and heritage, but can also help reduce the number of crimes related to cultural goods overall. In light of ongoing campaigns involving illegal excavation, looting, and pillage of cultural heritage, UN Security Council Resolution 2347 (2017) encourages Member States to create educational programmes at all levels on the protection of cultural heritage as well as raising public awareness about the illicit traffic of cultural property and its prevention (Paragraph 27(i)) [35].

While assessing the relative strengths and weaknesses of the UNESCO 1970 Convention, Lyndel V. Prott has pointed to education as one of the convention's main achievements. She reiterated that "the influence of the Convention in public education (Article 10) has led to the holding of many workshops on the topic, by UNESCO, by regional organisations, and by national administrations as well as by non-governmental organizations such as the International Council of Museums (ICOM). These important efforts at public education are reflected also in the 13 other cultural recommendations of UNESCO" [36] (p. 3). Ten years later, with the 50th anniversary of UNESCO 1970 Convention, we may add that international efforts have been undertaken, but the threats to cultural property still remain the same, if not more complex due to its use in terrorist financing and professional criminal networks dealing with illicit objects. Towards the end of 2020, a communication campaign titled "The Real Price of Art" was launched to draw attention to these issues. It raised much debate, as some objects displayed on the posters were taken from the Metropolitan Museum of Art's database (public domain). In order to avoid a misunderstanding regarding the provenance of the objects, all the pictures were eventually removed and changes were introduced to online publications [37]. This case demonstrates that educational campaigns are burdened with many risks and must be carefully prepared [38].

The educational dimension concentrates on the sensitization of individuals when acquiring objects and is strongly connected with the exercise of due diligence that "has emerged as a pivotal tool for responding to illicit trafficking in cultural property" and "is an important part in the toolkit for the fight against illicit trafficking" [39]. The cornerstone of due diligence in this context is Article 4 (4) UNIDROIT Convention: "In determining whether the possessor exercised due diligence, regard shall be had to all the circumstances of the acquisition, including the character of the parties, the price paid, whether the possessor consulted any reasonably accessible register of stolen cultural objects, and any other relevant information and documentation which it could reasonably have obtained, and whether the possessor consulted accessible agencies or took any other step that a reasonable person would have taken in the circumstances." This concept is standard setting and has a two-dimensional legal and ethical framework, as it is also found in professional ethical codes such as the ICOM Code of Ethics for Museums [40], the UNESCO International Code of Ethics for Dealers in Cultural Property [41], and the CINOA Code of Ethics [42]; and in ethical codes existing at the national level.

Educational activities should be coordinated by teaching institutions at all levels of education and lifelong learning programs as well as "through mass-media, museum, library, and other outreach programs" [43] (Paragraph 53). The means used are diverse: posters (for example, Italian poster Stop Trafico Illicito with a dismantled object and three red hands moving its parts in different directions), postcards, documentaries, and publications. Publications mostly emphasize the threat and consequences of illicit traffic and the model of desired conduct is presented in such cases [44]. Parallel awareness raising campaigns have been launched (\#Unite4Heritage campaign) with degrees of success. Activities have also been prepared for different target groups. For children, there are comics, short cartoons, infographics, and short films available on YouTube. These films not only present the typical 
cultural heritage from the region or country (for example Africa, Asia, Iraq, South East Asia), but also a warning on how theft, illegal export, and excavations can affect the region's culture. The activities show the connection between cultural heritage and identity (such as the campaign "Heritage is Identity, Don't Steal It") and aim to inform tourists who are often offered some objects with dubious or illegal provenance [45]. It should be noted, however, that this system has a major but not visible prima facie deficiency. The convention takes into account the interest of tribal, indigenous, or other communities and grants protection to their cultural artifacts in a very "paternalistic way". These communities cannot raise claims based on the convention and must rely on cooperation with the state for the return of cultural objects. As a result, a special focus on and active participation of the members of these communities are needed in awareness raising programs, especially considering the fact that the scale of cultural property losses originating from these communities is alarming.

\subsection{The 1972 UNESCO Convention}

Scientific and research work fuelled by the political will of the 1960s made it possible to adopt the 1972 UNESCO Convention in Paris and introduce a new international law instrument to protect cultural sites of global importance [46]. The World Heritage Convention (WHC) [7] is the first international document uniting the natural world with the man-made world, and covering both cultural heritage (monuments, groups of buildings, - Article 1) and natural heritage (natural features, geological and physiographical formations, natural sites-Article 2). The international act seeks a balance between the use of cultural heritage and the need to preserve such heritage for future generations. Since 1992, the natural and cultural heritage falling under the convention are administered jointly by the World Heritage Centre [15] (p. 78).

The convention indicates the existence of humankind's common heritage and the need to protect it for the common interest of individual States Parties as well as the international community [47]. The primary duty of States Parties is to identify, protect, conserve, present, and pass on cultural and natural heritage to future generations. Natural and cultural heritage is recognised as having universal value and the international community is obliged to cooperate. The Convention does not affect the sovereignty and property rights in national legislation, but rather acts in addition to them.

A permanent and desirable solution adopted in the document is the registry of cultural and natural heritage on the World Heritage List (hereinafter: WHL). Properties having outstanding universal value (OUV) are entered upon the request of a State Party. Moreover, a List of World Heritage in Danger has been established. This danger may be the result not only of military action or natural disasters, but also of rapid urban development and uncontrolled tourism.

Parties are required to develop and implement education and information programmes aimed at reinforcing respect for and attachment to cultural and natural heritage (Article 27) [48] (p. 86) as per the chapter titled Education Programmes. The programmes should also give particular emphasis to natural and cultural assets that are under threat. Under a further regulation, States which have benefited from international assistance provided under the 1972 UNESCO Convention are obliged to inform this fact that and to indicate the amount received as part of such assistance and the work for which it has been specifically allocated. These informational activities are intended to strengthen the impact and respect for world heritage among local or national communities [49]. Olaia Fontal points out that education has also formed "an essential discipline in the management of cultural heritage" by addressing the pivotal issues of identity and cultural belonging [50].

Operational guidelines have been devised for such conventions to facilitate their implementation [51]. Guidelines relating to Articles 27 and 28 of the WHC are given in Chapters VI-VIII. The objectives of support for the 1972 UNESCO Convention are: to enhance capacity building and research; to raise the general public's awareness, understanding and appreciation of the need to preserve cultural and natural heritage; to enhance 
the function of World Heritage in the life of the community; and to increase equitable, inclusive and effective participation of local and national populations, including indigenous peoples, in the protection and presentation of heritage (Paragraph 211). Member States should prepare appropriate strategies regarding the training of professionals who are responsible for the relevant research and for carrying out work to protect heritage (Paragraphs213, 214 bis). At the same time, educational and promotional activities are to be carried out in order to raise public awareness of the need to preserve world heritage (Paragraph217). Marketing and promotion of WHL facilities is appropriate, and also has the support of the UNESCO Secretariat.

World Heritage $(\mathrm{WH})$ should be afforded a prominent place in the curricula of schools and universities. It is recommended that schools, universities, museums, and other local and national educational authorities be involved in quality educational activities in the field of WH protection (Paragraphs 217-219). An important element of these activities is the World Heritage Educational Resource Kit "World Heritage in Young Hands" prepared by UNESCO agencies. The Young Hands Kit currently has 38 language versions compromising six chapters, including educational issues, heritage identification, tourism, environment and cultural activities for peace. Under the World Heritage Fund (Article 15), States may apply for financial support covering assistance in the field of education and research, assistance in technical cooperation and assistance in promotion and education. The form of activities financed from the Fund's resources may include preparation and publication of publications on $\mathrm{WH}$ or the organisation of meetings promoting the ideas within the convention.

Property included on the World Heritage List should be marked with an identifying emblem. The emblem was designed by Michel Olyff and symbolizes the interdependence of cultural and natural properties. The public display of the symbol is to promote knowledge about the Convention itself. The World Heritage List, and thus the emblem, have attained global recognition [52]. The emblem can be used as part of promotional activities in tourism, as well as for the revitalisation or sustainable development of cities and regions. Lynn Meskell argues that "increasing heritage destruction uncomfortably suggests that there is something specific about the World Heritage stamp that has rendered sites valuable targets" and mentions sites with international legal status, funding and visibility [53] (p. 192). When referring to such globally recognized cases of intentional heritage destruction, such as Timbuktu in Mali and the Bamiyan Buddhas, she points out that "their internationalism may be at heart of their destruction" [53] (p. 192). Therefore, this aspect additionally strengthens the need for prominent educational campaigns addressing all stakeholders, especially local communities, since their involvement is a requisite of cultural heritage management. Recovery following cultural heritage destruction constitutes a complex and long-lasting process; its integral parts should consist of education and awareness-raising at all channels together with promotion of knowledge and respect for the diversity of cultures and heritage [54]. Although the text of the convention does not address the issue of indigenous and tribal communities, the involvement of those communities is crucial in terms of cultural heritage management sites. While submitting a new proposal for the WHL, each State must deliver a special management plan for the site, including a participatory model. Therefore, it is advisable to give the management of the site to communities that are the best qualified when it comes to interpreting and teaching others about their heritage. Even without modifying the convention, it is possible to find a progressive interpretation and develop a cultural community with a sensitive and sustainable model of heritage preservation.

\subsection{The 2001 UNESCO Convention}

Underwater cultural heritage is being widely explored due to recent technological developments. Therefore, it is exposed to grave threats such as looting and destruction. There are many "explorers" dreaming of "wrecked galleons full of gold, the Amber Chamber (Amber Room)" [55] or warships of all eras. The knowledge related to the context of a 
find's location and the cultural and natural environment surrounding them is of extreme importance, as it provides researchers with useful information. When studying shipwrecks, it should be remembered that they are also human graves, and human remains should be respected. In order to achieve this goal, among others, the UNESCO 2001 Convention [8] was adopted, complementing the UNESCO conventions of 1956, 1970, and 1972 [56].

Under this convention, underwater cultural heritage is res extra commercium [57] (p. 315) and cannot be commercially exploited [58] (pp. 131-133). Rule 2 of the Annex to the 2001 UNESCO Convention reiterates: "The commercial exploitation of underwater cultural heritage for trade or speculation or its irretrievable dispersal is fundamentally incompatible with the protection and proper management of underwater cultural heritage. Underwater cultural heritage shall not be traded, sold, bought or bartered as commercial goods". Although the convention refers to commercial exploitation, it does not regulate ownership. Sarah Dromgoole believes that excluding the issue of property from the scope of the 2001 UNESCO Convention was a pragmatic solution, making it possible to advance work on this convention and also to include warships in its scope [59] (p. 117). Due to Article 2, among various purposes and general principles, the aim of creating public awareness, appreciation, and protection of the cultural heritage under water has been highlighted. At the same time, the observation of underwater cultural heritages in situ is permitted, as long as this does not jeopardise their protection. This is due to the fact that underwater heritage should not be excavated, unless non-intervention at the site leads to irreversible damage. States Parties should undertake activities that have educational merit to raise public awareness on the value of underwater cultural heritage and its protection (Article 20). This is particularly important in areas rich in underwater heritage, which can contribute to the development of a region or country [60]. Education is mentioned among the activities undertaken by competent authorities established by States Parties (effective protection, conservation, presentation, and management of underwater cultural heritage research) to ensure the convention's proper implementation (Article 22).

According to Rule 35 of the convention, documentation related to underwater research should be widely disseminated: "Projects shall provide for public education and popular presentation of the project results where appropriate". Such activity has educational value as well. It shows the richness of underwater heritage and highlights the scale of research and the effectiveness of the funds spent, including public funds, on research in this area. Educational campaigns are useful tools used to change public opinion and fight the illicit traffic of underwater cultural heritage. Information directed towards the public also forms part of individuals' right to access information about cultural heritage [61] (pp. 306-307).

In the Manual for Activities Directed at Underwater Cultural Heritage, three target groups were mentioned: children, divers, and local communities [61] (pp. 310-314). The development of new technologies offers opportunities for underwater exploration, but also provides a wide range of water sports that are the driving force behind the development of tourism; for example, in coastal areas. Consequently, it seems that educational measures should be taken not only amongst the local community, but also targeted towards potential international tourists.

\subsection{The 2003 and 2005 UNESCO Conventions}

Another international legal act on the protection of cultural heritage is the 2003 UNESCO Convention [9]. Its implementation was preceded by a lively discussion [62] and a wide range of activities promoting the protection of intangible cultural heritage (ICH) [63] (pp. 16ff.). An important aspect of this convention was granting cultural communities, as well as individuals, protection over their cultural heritage [64] (pp. 45-47). This approach to protection is associated with the recognition of the need to protect oral culture, cultural, social and religious rituals, and all the knowledge and skills that make up ICH [62].

Recognising the role of traditional cultures and ICH, the 2003 UNESCO Convention placed particular emphasis on education, awareness-raising, and the development of com- 
munities' potential. In accordance with Article 14, States Parties should take appropriate measures to ensure recognition, respect, and promotion of ICH in its various forms. In Operational Directives [65] (Paragraph 107), many examples of formal and non-formal educational measures were mentioned. By those measures, "States Parties shall endeavour, by all appropriate means, to ensure recognition of, respect for and enhancement of intangible cultural heritage through educational and information programmes". Amongst the available educational measures, social media (information and communication technologies) was mentioned. It must be emphasized that the educational dimension of ICH not only consists of raising awareness, but also aims at vocational guidance and management of small businesses dealing with ICH, which links it strongly to an individual's development.

The educational programmes aimed at the international community and especially at young people, and the directional programmes aimed at interested communities and groups, were mentioned as examples of such actions. Furthermore, emphasis has been placed on activities that foster the development of ICH protection potential at the level of scientific research and cultural management. As intangible culture is often of a local and oral nature, actions should also be carried out to promote the informal transfer of knowledge. This can be interpreted as the promotion and support of local communities to present their culture in an unconditional manner, without the involvement of state patronage but sharing mutual interest. Moreover, the informal elements should be conveyed in the promotion of ICH across a broad spectrum of media in order to reach society as a whole, especially young people [66] (pp. 74-75).

Therefore, special attention should be paid to grassroots activities in social media and supporting them to ensure that they do not become short-lived ephemera. This will allow them to develop and engage in the protection of ICH. Due to the fact that ICH often involves ethnic, cultural, and linguistic minorities, all activities, especially those of an educational nature, should be designed with the participation of these groups. Stakeholders must have the opportunity to actively manage ICH and articulate their needs in the educational sphere to promote this heritage. States undertake these obligations in various forms with different methodologies. Recognising those differences, the need for sharing good practices and experience in PR campaigns and awareness-raising programs has been identified and prioritised [67].

Within the framework of educational and promotional programmes, a special place should be given to activities that include a Representative List of the intangible cultural heritage of humanity deriving from Articles 16-17 of the 2003 UNESCO Convention. It seems likely that ICH might obtain great recognition and respect due to appropriate educational activities.

The work on the 2003 UNESCO Convention was accompanied by a discussion on other aspects of cultural heritage protection. In this spirit, the 2005 UNESCO Convention [10] was adopted two years later. Blake argues that the 2003 and 2005 UNESCO Conventions were siblings [62] and their adoption was a consequence of the Declaration on Cultural Diversity [68]. At the same time, the 2005 UNESCO Convention was intended to form a response towards progressive globalisation and a liberalisation of the market at the global level [69]. In parallel with this objective, it aimed to provide important measures in terms of sustainable development [70]. The scope of the convention covered not only purely artistic activities, but all kinds of cultural expressions, such as culinary traditions, online activities, computer games, as well as various forms of recreation or sport, and thus all activities with cultural elements [71]. The 2005 UNESCO Convention also paid particular attention to the involvement of audiences and artists in cultural expression.

It is fully understood and accepted that cultural diversity is important in terms of the identity of countries, peoples, ethnic groups and cultural heritage. $\mathrm{CHE}$ and public awareness activity is set forth in the Article 10a of the 2005 UNESCO Convention. States Parties are required to "promote public understanding of the importance of protecting and promoting the diversity of cultural expressions through educational and public awareness programmes, etc." [72] (pp. 218-219) together with exchanges in the sphere of cultural 
activities, to preserve traditional forms of cultural expression. States Parties are obliged to cooperate with other parties and international or regional organizations to this end (Article 10b).

In light of the Operational Guidelines [72], States Parties are responsible for further promoting an understanding of the value of protection and diversity in cultural expressions. This is meant to be achieved through formal and informal educational programmes enabling cultural participation [73] (p. 227). The target group is broad, regardless of the level of education, age, social status, cultural affiliation, or economic situation. Culture should be systematically, ideologically, and politically correlated with national educational systems to achieve the best results.

In view of rapid changes to local and global societies, cultural and educational institutions should stimulate continuous dialogue in order to adapt to changes, and even to design solutions. This is particularly important when considering the economy and the 4th industrial revolution, which is based on digital systems with significant cultural implications. The private sector's role in creating sustainable development in this area is paramount. The formal education of children and young people must form an important element in promoting and using the diversity of cultural expressions. At the same time, engaging parents in the design of programmes for the diversity of cultural expressions among children and young people may also be an opportunity to actively engage adults in the cultural sphere, as a direct result of the guidelines' successful implementation.

\section{Conclusions}

The analysis of UNESCO cultural conventions on the educational framework allows some conclusions to be drawn. Cultural heritage education is strongly anchored in the conventions' texts. In each convention, educational and promotional activities are usually regulated in a separate editorial unit or several interrelated units. The role of educational activities is emphasized in both Operational Guidelines and Directives. The provisions regarding education and awareness-raising activities are not presented as core measures for States Parties; however, the proper implementation of the conventions strongly depends on them.

Cultural heritage education is foreseen not only at the UNESCO level but also at the Member States level. The scope of educational activities is linked with the number of ratifications. Information and public awareness-building remain important aspects of responsible cultural heritage management at all levels of education.

The educational activities of States Parties are strongly linked to promotion, especially when it comes to World Heritage Sites and intangible cultural heritage. Cultural heritage education should be considered in terms of different target groups using tailored tools (cartoons, online games, conferences, webinars, reports). The activities should be addressed towards society as a whole, devoted in particular to children and young people to raise awareness among them and present the value of cultural heritage.

One may form the impression that UNESCO educational activities are fragmented and compartmentalised. The overarching goal is to protect cultural heritage, but there is a lack of synergy originating from the separate budgets, funds established within conventions, and plans adopted within the UNESCO budget. Each activity is not launched in a vacuum, but should complement those already in existence. The PR campaigns and cooperation with UNESCO's institutional partners and stakeholder tools should be prepared as part of a broad educational program. Despite this lack of synergy and the resulting creation of education-related programs in convention-related siloes, UNESCO has managed to create a uniform and evolving system of educational measures aimed at various stakeholders and focusing on various awareness levels.

Generally, we may divide stakeholders that require educational or promotional programs into three groups: "makers", "users", and "bystanders". The Makers are mainly public entities responsible for setting and implementing the policies. They require a strong educational and practical background in cultural heritage studies, understood as an in- 
terdisciplinary field of action. Thus, they are natural targets for formal (academic and executive) and informal educational actions, action learning, and reflective practice. Users are persons and entities applying the conventions in their professional practice (e.g., soldiers, customs and police officers, art merchants, museum curators, etc.) or as part of their non-professional activities (e.g., divers, hobby treasure-hunters, community activists). They require various levels of knowledge of relevant UNESCO conventions, varying from in-depth academic specialization to "Swiss Army Knife" solutions like playing cards for soldiers. Finally, the largest group are "Bystanders"- persons who face the subject-matter of UNESCO conventions only accidentally, but who have to be aware of their basics. This is the least uniform group from these three. Bystanders include tourists buying "antiquities" while visiting a foreign country, students discovering new artifacts as a surprise part of their school project or members of local communities upholding traditional crafts and customs. The UNESCO cultural conventions recognise all three groups and provide national governments with guidelines and incentives for creating educational and awareness-raising programs for various stakeholders. It seems that the UNESCO framework for heritage education was at least fit for purpose during the pre-pandemic era; however, recent events may require the adoption of new educational formats.

The current COVID-19 crisis challenges contemporary cultural heritage education in myriad ways. To enable users to navigate cultural heritage websites easily, it is advisable to prepare an educational platform with links to the requisite materials, links, and videos. An intuitive and user-friendly platform is also recommended. The threats to cultural property can appear in situ or online, such as online auctions where looted or illegally exported objects are offered for sale. Therefore, Internet actions should complement the ones undertaken via other channels and direct tools [74]. The COVID-19 and post-pandemic challenges are not fully understood yet and should be an object of further research and analysis. At this point, we may only assume that online educational measures will be part of the "new normal" and that digital participation in heritage appreciation will require novel educational means, which may include "Internet policing" similar to that provided by digital security software labelling websites as "safe" and by software and organizations fact-checking online news.

Author Contributions: Conceptualization, A.J.-B., M.P. and P.S.; methodology, A.J.-B., M.P., and P.S.; formal analysis, A.J.-B., M.P., and P.S.; investigation, A.J.-B., M.P., and P.S.; resources, A.J.-B., M.P., P.S.; writing-original draft preparation, A.J.-B., M.P. and P.S.; writing—review and editing, A.J.-B.; project administration, A.J.-B.; funding acquisition, A.J.-B. and P.S. All authors have read and agreed to the published version of the manuscript.

Funding: This article/chapter is a part of the research project "Legal forms of cultural heritage governance in Europe-a comparative law perspective", No. UMO-2019/35/B/HS5/02084, financed by the National Science Centre (Poland).

Institutional Review Board Statement: Not applicable.

Informed Consent Statement: Not applicable.

Conflicts of Interest: The authors declare no conflict of interest.

\section{References}

1. Constitution of the United Nations Educational, Scientific and Cultural Organization. Adopted in London on 16 November 1945 and Amended by the General Conference at Its 2nd-40th Sessions. Available online: https://unesdoc.unesco.org/ark: /48223/pf0000372956/PDF/372956eng.pdf.multi.page=6 (accessed on 14 January 2021).

2. UNESCO Snapshots. 2020. Available online: https:/ / unesdoc.unesco.org/ark:/48223/pf0000375163 (accessed on 14 January 2021).

3. Convention for the Protection of Cultural Property in the Event of Armed Conflict with Regulations for the Execution of the Convention 1954, 249 UNTS 240. Available online: http:/ / portal.unesco.org/en/ev.php-URL_ID=13637\&URL_DO=DO_TOPIC\& URL_SECTION=201.html (accessed on 14 January 2021). 
4. Protocol to the Convention for the Protection of Cultural Property in the Event of Armed Conflict 1954, The Hague. 14 May 1954. Available online: http:/ / portal.unesco.org/en/ev.php-URL_ID=15391\&URL_DO=DO_TOPIC\&URL_SECTION=201.html (accessed on 14 January 2021).

5. Second Protocol to the Hague Convention of 1954 for the Protection of Cultural Property in the Event of Armed Conflict, The Hague, 26 March 1999. Available online: http:/ / portal.unesco.org/en/ev.php-URL_ID=15207\&URL_DO=DO_TOPIC\&URL_ SECTION=201.html (accessed on 14 January 2021).

6. Convention on the Means of Prohibiting and Preventing the Illicit Import, Export and Transfer of Ownership of Cultural Property, Paris, 14 November 1970. Available online: http:/ / portal.unesco.org/en/ev.php-URL_ID=13039\&URL_DO=DO_TOPIC\&URL_ SECTION=201.html (accessed on 14 January 2021).

7. Convention Concerning the Protection of the World Cultural and Natural Heritage, Paris. 16 November $1972 . \quad$ Available online: http://portal.unesco.org/en/ev.php-URL_ID=13055\&URL_DO=DO_TOPIC\&URL_SECTION=201.html (accessed on 14 January 2021).

8. Convention on the Protection of the Underwater Cultural Heritage, Paris. 2 November 2001. Available online: http:/ / portal. unesco.org/en/ev.php-URL_ID=13520\&URL_DO=DO_TOPIC\&URL_SECTION=201.html (accessed on 14 January 2021).

9. Convention for the Safeguarding of the Intangible Cultural Heritage, Paris. 17 October 2003. Available online: http:/ / portal. unesco.org/en/ev.php-URL_ID=17716\&URL_DO=DO_TOPIC\&URL_SECTION=201.html (accessed on 14 January 2021).

10. Convention on the Protection and Promotion of the Diversity of Cultural Expressions, Paris. 20 October $2005 . \quad$ Available online: http://portal.unesco.org/en/ev.php-URL_ID=31038\&URL_DO=DO_TOPIC\&URL_SECTION=201.html (accessed on 14 January 2021).

11. Blake, J. On defining the cultural heritage. Int. Comp. Law Q. 2000, 49, 61-85. [CrossRef]

12. Vecco, M. A definition of cultural heritage: From the tangible to the intangible. J. Cult. Herit. 2010, 11, 321-324. [CrossRef]

13. Natsuko, A. Rethinking the global heritage discourse-Overcoming 'East' and 'West'? Int. J. Herit. Stud. 2016, 22, 14-25. [CrossRef]

14. Fadel, J.C.; Groff, J.S. Four-dimensional education for sustainable societies. In Sustainability, Human Well-Being, and the Future of Education; Cook, W., Ed.; Palgrave Macmillan: Cham, Switzerland, 2019. [CrossRef]

15. Landorf, H.; Doscher, S.; Rocco, T. Education for sustainable human development towards a definition. Theory Res. Educ. 2008, 6, 221-236. [CrossRef]

16. Category 2 Institutes and Centres under the Auspices of UNESCO and UNITWIN Networks/UNESCO Chairs Related to the Culture Sector. Available online: https:/ / en.unesco.org/events/second-coordination-meeting-unesco-category-2-institutes-andcentres-under-auspices-unesco (accessed on 14 January 2021).

17. Jagielska-Burduk, A.; Stec, P. Council of Europe Cultural Heritage and Education Policy: Preserving Identity and Searching for a Common Core? Rev. Electrónica Interuniv. Form. Profr. 2019, 22. [CrossRef]

18. Jagielska-Burduk, A. Cultural heritage, education and research in the European Union. In Cultural Heritage in the European Union: A Critical Inquiry into Law and Policy; Jakubowski, A., Hausler, K., Fiorentini, F., Eds.; Brill Nijhoff: Leiden, The Netherlands, 2019; ISBN 978-90-04-36533-9.

19. Nahlik, S.E. Grabież Dzieł Sztuki: Rodowód Zbrodni Międzynarodowej; Zakład Narodowy im. Ossolińskich: Wrocław, Poland, 1958.

20. O'Keefe, P.J.; Prott, L.V. (Eds.) Cultural Heritage Conventions and Other Instruments: A Compendium with Commentaries; Institute of Art and Law: Builth Wells, UK, 2011; ISBN 978-1-903987-12-4.

21. Chamberlain, K. War and Cultural Heritage: An Analysis of the 1954 Convention for the Protection of Cultural Property in the Event of Armed Conflict and Its Two Protocols; Institute of Art and Law: Leicester, UK, 2004; ISBN 978-1-903987-06-3.

22. Techera, E.J. Protection of cultural heritage in times of armed Conflict: The international legal framework revisited. Macquarie J. Int. Comp. Environ. Law 2007, 4, 1-20.

23. Schreiber, H. Komentarz do art. 7. In Konwencje UNESCO W Dziedzinie Kultury: Komentarz; Zalasińska, K., Ed.; Lex a Wolters Kluwer Business: Warsaw, Poland, 2014; ISBN 978-83-264-3157-9.

24. O'Keefe, R. The Protection of Cultural Property in Armed Conflict; Cambridge University Press: Cambridge, UK, 2006; ISBN 978-0-511-26088-9.

25. O'Keefe, R.; Péron, C.; Musayev, T.; Ferrari, G. Protection of Cultural Property. Military Manual; United Nations Educational, Scientific and Cultural Organization: Paris, France, 2016; ISBN 978-92-3-100184-0.

26. Kila, J.D. Military involvement in cultural property protection as part of preventive conservation. In Cultural Heritage in the Crosshairs; Kila, J.D., Zeidler, J., Eds.; Brill: Leiden, The Netherlands, 2013; ISBN 978-90-04-24781-9.

27. NATO Legal Gazette. Issue 38. Cultural Property Protection: NATO and Other Perspectives. 2017. Available online: https: //www.act.nato.int/images/stories/media/doclibrary/legal_gazette_38.pdf (accessed on 19 October 2020).

28. Rosén, F. NATO and Cultural Property: Embracing New Challenges in the Era of Identity Wars; Nordic Center for Cultural Heritage and Armed Conflict: Copenhagen, Denmark, 2017; ISBN 978-87-970264-0-3.

29. NATO Cultural Property Protection. Available online: http://www.nato.int/cps/en/natohq/topics_166114.htm (accessed on 19 October 2020).

30. UNIDROIT Convention on Stolen or Illegally Exported Cultural Objects, Rome. 24 June 1995. Available online: https://www. unidroit.org/english/conventions/1995culturalproperty/1995culturalproperty-e.pdf (accessed on 14 January 2021). 
31. Cornu, M. Fighting Illicit Trafficking in Cultural Objects, Searching for Provenance and Exercising Due Diligence in the European Union (Joint European Commission-UNESCO Project, "Engaging the European Art Market in the Fight Against the Illicit Trafficking of Cultural Property". Study for the Capacity-Building Conference, 20-21 March 2018). Available online: http: //www.unesco.org/new/fileadmin/MULTIMEDIA/HQ/CLT/images/630X300/Study_Prof_Cornu_EN_01.pdf (accessed on 14 January 2021).

32. Renold, M.-A. The Legal and Illegal Trade in Cultural Property to and Throughout Europe: Facts, Findings and Legal Analysis (Joint European Commission-UNESCO Project, "Engaging the European Art Market in the Fight against the Illicit Trafficking of Cultural Property". Study for the Capacity-Building Conference, 20-21 March 2018). Available online: http:/ / www.unesco.org/ new / fileadmin/MULTIMEDIA/HQ/CLT/images/630X300/Study_Prof_Renold_EN_02.pdf (accessed on 14 January 2021).

33. Legal and Practical Measures Against Illicit Trafficking in Cultural Property: UNESCO Handbook; CLT/CH/INS-06/22; International Standards Section, Division of Cultural Heritage: Paris, France, 2016.

34. Boz, Z. Fighting the Illicit Trafficking of Cultural Property: A Toolkit for European Judiciary and Law Enforcement; United Nations Educational, Scientific and Cultural Organization: Paris, France, 2018; ISBN 978-92-3-100289-2.

35. Resolution 2347 (2017), Adopted by the Security Council at Its 7907th Meeting, on 24 March 2017, S/RES/2347 (2017). Available online: https: / / www.undocs.org/S /RES/2347\%20(2017) (accessed on 14 January 2021).

36. Prott, L.V. Strengths and Weaknesses of the 1970 Convention: An Evaluation 40 Years after Its Adoption; CLT/2011/CONF.207/7; UNESCO: Paris, France, 2011.

37. The Real Price of Art: International UNESCO Campaign Reveals the Hidden Face of Art Trafficking. Available online: https:/ / en.unesco.org/news/real-price-art-international-unesco-campaign-reveals-hidden-face-art-trafficking (accessed on 14 January 2021).

38. Kenney, N. Unesco under Fire for Using Met Objects in Anti-Trafficking Campaign. The Art Newspaper. 13 November 2020. Available online: http://www.theartnewspaper.com/news/facing-complaint-unesco-pulls-misleading-images-fromadvertisements-about-illicit-art-trafficking (accessed on 14 January 2021).

39. Subsidiary Committee of the Meeting of States Parties to the UNESCO Convention on the Means of Prohibiting and Preventing the Illicit Import, Export and Transfer of Ownership of Cultural Property (UNESCO, Paris, 1970), Seventh Session, UNESCO Headquarters, Room XI, 22 and 23 May 2019, Item 8a of the Provisional Agenda: Due Diligence, April 2019, C70/19/7.SC/8a. Available online: http:/ / www.unesco.org/new/fileadmin/MULTIMEDIA/HQ/CLT/movable/images/FINAL_SC_Duediligence_EN.pdf (accessed on 14 January 2021).

40. International Council of Museums Code of Ethics. Available online: https://icom.museum/en/resources/standards-guidelines/ code-of-ethics / (accessed on 14 January 2021).

41. UNESCO International Code of Ethics for Dealers in Cultural Property. Available online: http://www.unesco.org/new/en/ culture/themes/illicit-trafficking-of-cultural-property/legal-and-practical-instruments/unesco-international-code-of-ethicsfor-dealers-in-cultural-property/ (accessed on 14 January 2021).

42. CINOA Code of Ethics. Available online: https://www.cinoa.org/cinoa/codeofethics (accessed on 14 January 2021).

43. Operational Guidelines for the Implementation of the Convention on the Means of Prohibiting and Preventing the Illicit Import, Export and Transfer of Ownership of Cultural Property (UNESCO, Paris, 1970). Available online: https://en.unesco.org/sites / default/files/operational_guidelines_en_final_final.pdf (accessed on 14 January 2021).

44. UNESCO Office Havana and Regional Bureau for Culture in Latin America and the Caribbean. Culture and Development. Stop the Illicit Traffic of Cultural Heritage. Available online: https://unesdoc.unesco.org/ark:/48223/pf0000225521 (accessed on 14 January 2021).

45. UNESCO YouTube Channel. Available online: https:/ / www.youtube.com/user/unesco (accessed on 14 January 2021).

46. Cleere, H. The 1972 UNESCO world heritage convention. Herit. Soc. 2011, 4, 173-186. [CrossRef]

47. Turtinen, J. Globalising Heritage-On UNESCO and the Transnational Construction of a World Heritage; SCORE Rapportserie 2000:12; Stockholm Center for Organizational Research: Stockholm, Sweden, 2000; ISBN 978-91-7265-201-9.

48. Fontal, O; Martínez, M. Evaluación de programas educativos sobre Patrimonio Cultural Inmaterial. ESTPED 2017, 43, 69-89. [CrossRef]

49. Vujicic-Lugassy, V.; Richon, M. Art.27-28 Educational Programmes. In The 1972 World Heritage Convention: A Commentary; Francioni, F., Lenzerini, F., Eds.; Oxford University Press: Oxford, UK, 2008; ISBN 978-0-19-929169-4.

50. Fontal, O.; Rodríguez, M.M. The heritage and education research network: Place value on cultural heritage in Europe. In Handbook of Research on Citizenship and Heritage Education; Delgado, E., Cuenca, J.M., Eds.; IGI Global: Hershey, PA, USA, 2020; pp. 173-196.

51. Operational Guidelines for the Implementation of the World Heritage Convention, 10 July 2019, WHC.19/01. Available online: https:/ / whc.unesco.org/en/guidelines/ (accessed on 14 January 2021).

52. Rodwell, D. The Unesco World Heritage Convention, 1972-2012: Reflections and Directions. Hist. Environ. 2012, 3 , 64-85. [CrossRef]

53. Meskell, L. A Future in Ruins: UNESCO, World Heritage, and the Dream of Peace; Oxford University Press: New York, NY, USA, 2018; ISBN 978-0-19-064835-0.

54. Marcinkowska, M.; Zalasińska, K.; Lipska, D. (Eds.) The Challenges of World Heritage Recovery; Narodowy Instytut Dziedzictwa: Warsaw, Poland, 2019; ISBN 978-83-66160-36-1. 
55. Nazi Shipwreck Found off Poland May Solve Amber Room Mystery. The Guardian. 1 October 2020. Available online: http: //www.theguardian.com/world/2020/oct/01/nazi-shipwreck-found-off-poland-may-solve-amber-room-mystery (accessed on 14 January 2021).

56. Forrest, C. A New international regime for the protection of underwater cultural heritage. Int. Comp. Law Q. 2002, 51, 511-554. [CrossRef]

57. O'Keefe, P.J. Underwater cultural heritage. In The Oxford Handbook of International Cultural Heritage Law; Francioni, F., Vrdoljak, A.F., Eds.; Oxford University Press: Oxford, UK, 2020; ISBN 978-0-19-189228-8.

58. O'Keefe, P.J. Commercial exploitation: Its prohibition in the UNESCO convention on protection of the underwater cultural heritage convention 2001 and other instruments. Art Antiq. Law 2013, 18, 129-148.

59. Dromgoole, S. Underwater Cultural Heritage and International Law; Cambridge University Press: Cambridge, UK, 2013; ISBN 978-0-521-84231-0.

60. Operational Guidelines for the Convention on the Protection of the Underwater Cultural Heritage, CLT/HER/CHP/OG 1 REV. Available online: https:/ / unesdoc.unesco.org/ark:/48223/pf0000234177 (accessed on 14 January 2021).

61. Maarleveld, T.J.; Egger, B.; Guérin, U. (Eds.) Manual of Activities Directed at Underwater Cultural Heritage: Guidelines to the Annex of the UNESCO 2001 Convention; United Nations Educational, Scientific and Cultural Organization: Paris, France, 2013; ISBN 978-92-3-001122-2.

62. Blake, J. From traditional culture and folklore to intangible cultural heritage: Evolution of a treaty. Santander Art Culture Law Rev. 2017, 2, 41-60. [CrossRef]

63. Aikawa-Faure, N. From the proclamation of masterpieces to the convention for the safeguarding of intangible cultural heritage. In Intangible Heritage; Smith, L., Akagawa, N., Eds.; Routledge: London, UK, 2009; ISBN 978-0-415-47396-5.

64. Blake, J. UNESCO's 2003 convention on intangible cultural heritage: The implications of community involvement in 'safeguarding.' In Intangible Heritage; Smith, L., Akagawa, N., Eds.; Routledge: London, UK, 2009; ISBN 978-0-415-47396-5.

65. Operational Directives for the Implementation of the Convention for the Safeguarding of the Intangible Heritage, 7.GA (2018). Available online: https://ich.unesco.org/doc/src/ICH-Operational_Directives-7.GA-PDF-EN.pdf (accessed on 14 January 2021).

66. Blake, J. Commentary on the 2003 UNESCO Convention on the Safeguarding of the Intangible Cultural Heritage; Institute of Art and Law: Leicester, UK, 2006; ISBN 978-1-903987-09-4.

67. Blake, J. Article 14: Education, awareness-raising and capacity-building. In The 2003 UNESCO Intangible Heritage Convention: A Commentary; Blake, J., Lixinski, L., Eds.; Oxford University Press: Oxford, UK, 2020; ISBN 978-0-19-882478-7.

68. UNESCO Universal Declaration on Cultural Diversity, 2 November 2001, UNESCO Doc. 31C/Res 25. Available online: http: / / portal.unesco.org/en/ev.php-URL_ID=13179\&URL_DO=DO_TOPIC\&URL_SECTION=201.html (accessed on 14 January 2021).

69. Hahn, M. A Clash of cultures? The UNESCO diversity convention and international trade law. J. Int. Econ. Law 2006, 9, 515-552. [CrossRef]

70. Galera, M.D.S. Educational and Cultural Challenges of the European Sustainability Model Breaking Down Silos in the Legal Domain; Springer: Cham, Switzerland, 2020; ISBN 978-3-030-38715-0. [CrossRef]

71. Smith, R.C. The UNESCO convention on the protection and promotion of the diversity of cultural expressions: Building a new world information and communication order? Int. J. Commun. 2007, 1, 24-55.

72. Blake, J. International Cultural Heritage Law; Oxford University Press: Oxford, UK, 2015; ISBN 978-0-19-872351-6.

73. Basic Texts of the 2005 Convention on the Protection and Promotion of the Diversity of Cultural Expressions, 2019 Edition, CLT-2019/WS/21. Available online: https:/ / unesdoc.unesco.org/ark:/48223/pf0000370521 (accessed on 14 January 2021).

74. Jagielska-Burduk, A. Uwarunkowania upowszechniania i promocji dziedzictwa kulturowego a narzędzia ICT—między prawem a ekonomią. Opol. Studia Adm. Prawne 2016, 14, 79-90. [CrossRef] 